\title{
Meconium ileus in the absence of cystic fibrosis
}

\author{
Khoulood Fakhoury, Peter R Durie, Henry Levison, Gerard J Canny
}

\begin{abstract}
Although meconium ileus in the absence of cystic fibrosis is considered a rare event, it was found that eight of 37 $(21 \cdot 6 \%)$ newborn infants with meconium ileus had no laboratory or clinical evidence of cystic fibrosis.
\end{abstract}

\section{(Arch Dis Child 1992;67:1204-6)}

Meconium ileus is the earliest clinical manifestation of cystic fibrosis in $10-20 \%$ of affected patients $\left(13.4 \%\right.$ at this clinic), ${ }^{1}$ but it is a rare phenomenon in patients who do not have this condition. We report eight neonates with meconium ileus, who had no clinical or laboratory evidence of cystic fibrosis.

\section{Pepartment}

Hospital for

Sick Children,

Toronto, Canada, Division of Chest Medicine

Khoulood Fakhoury

Henry Levison

Gerard J Canny

\section{Division of}

Gastroenterology

Peter R Durie

Correspondence to: Dr Gerard J Canny, Hospital for Sick Children 555 University Avenue, Toronto, Ontario, Canada M5G 1 X8.

Accepted 26 May 1992

\section{Patients, methods, and results}

During the six year period, 1986-91, 37 neonates with meconium ileus were seen at the Hospital for Sick Children, Toronto, Eight (four boys) of these 37 patients $(21.6 \%)$ were subsequently shown to have no laboratory evidence of cystic fibrosis, and they form the basis of this report.

The patients' characteristics are summarised in the table. Four of the eight infants were delivered prematurely (that is, less than 37 weeks' gestation), three of whom required intubation and mechanical ventilation at birth. Maternal complications included polyhydramnios (patients 4 and 7) and preeclampsia (patient 6), but there was no family history of cystic fibrosis. All presented with signs of intestinal obstruction with abdominal distension (with the exception of patient 5), and failure to pass meconium, and four infants developed ileal perforation. All except patient 5 required laparotomy, and three infants required bowel resection. Complications noted at surgery included ileal perforation, meconium peritonitis, meconium pseudocysts, ileal volvulus, and ileal atresia (table). Histopathology of the surgically resected specimens of small bowel revealed necrosis and haemorrhage, but lesions typical of cystic fibrosis ${ }^{2}$ or Hirschsprung's disease were not identified. Pilocarpine iontophoresis sweat chloride tests were normal on two occasions in all patients. Genetic studies were performed on six subjects, none of whom had the $\Delta \mathrm{F}_{508}$ deletion, which is present in $68 \%$ of patients with cystic fibrosis at this clinic. ${ }^{3} \mathrm{Six}$ of the eight infants had a favourable outcome and developed no gastrointestinal, nutritional, or pulmonary complications.

Patient 2, who was born at 30 weeks'gestation, required mechanical ventilation for 17 days and developed mild bronchopulmonary dysplasia. Patient 6 required continuous mechanical ventilation for 106 days for the respiratory distress syndrome, which resulted

Clinical data of the eight patients

\begin{tabular}{|c|c|c|c|c|c|c|}
\hline $\begin{array}{l}\text { Patient } \\
\text { No }\end{array}$ & Sex & $\begin{array}{l}\text { Gestational } \\
\text { age (weeks) }\end{array}$ & $\begin{array}{l}\text { Age at } \\
\text { presentation }\end{array}$ & $\begin{array}{l}\text { Birth } \\
\text { weight (g) }\end{array}$ & $\begin{array}{l}\text { Clinical } \\
\text { presentation }\end{array}$ & $\begin{array}{l}\text { Abdominal } \\
\text { radiograph }\end{array}$ \\
\hline 1 & $M$ & 36 & Day 2 & 2730 & $\begin{array}{l}\text { Formula feeds for } 24 \text { hours, } \\
\text { abdominal distension, vomiting } \\
\text { (bilious drainage by nagogastric } \\
\text { tube). No meconium passed } \\
\text { after } 24 \text { hours }\end{array}$ & $\begin{array}{l}\text { Distended loops with air-fluid } \\
\text { levels, no air in colon. } \\
\text { Barium enema: microcolon, } \\
\text { ? distal small bowel atresia }\end{array}$ \\
\hline 2 & $M$ & 30 & Day 3 & 730 & $\begin{array}{l}\text { Ventilated for RDS ( } 17 \text { days): } \\
\text { not fed, developed abdominal } \\
\text { distension, periumbilical erythema. } \\
\text { No meconium passed by day } 2 \text {. }\end{array}$ & $\begin{array}{l}\text { Dilated loops (day 1), free air } \\
\text { in the abdomen (day } 3 \text { ) }\end{array}$ \\
\hline 3 & $\mathrm{~F}$ & 40 & At birth & 3210 & $\begin{array}{l}\text { Not fed, developed abdominal } \\
\text { distension. No meconium passed; } \\
\text { bilious drainage by nasogastric tube }\end{array}$ & $\begin{array}{l}\text { No abdominal gas; microcolon; } \\
\text { calcification in RIF. } \\
\text { ? Meconium cyst }\end{array}$ \\
\hline 4 & $M$ & 35 & Day 2 & 2630 & $\begin{array}{l}\text { Low Apgar scores-ventilated for } \\
24 \text { hours: not fed, developed } \\
\text { ascites and raised serum } \\
\text { transaminase values on day } 2 \text {. } \\
\text { No meconium passed by day } 2\end{array}$ & $\begin{array}{l}\text { No abdominal gas. Barium } \\
\text { enema: malrotation, } \\
\text { proximal dilation of small } \\
\text { bowel with free air in the } \\
\text { abdomen }\end{array}$ \\
\hline 5 & $\mathrm{~F}$ & 40 & 12 hours & 3120 & $\begin{array}{l}\text { Breast fed, bilious vomiting. } \\
\text { No meconium passed }\end{array}$ & $\begin{array}{l}\text { Barium meal: ?mass in RIF, } \\
\text { barium enema: patchy filling } \\
\text { defects in colon and the last } \\
10 \mathrm{~cm} \text { of ileum }\end{array}$ \\
\hline 6 & $\mathrm{~F}$ & 27 & Day 2 & 870 & $\begin{array}{l}\text { Ventilated for RDS (106 days): } \\
\text { not fed, abdominal distension. } \\
\text { No meconium passed by day } 3\end{array}$ & $\begin{array}{l}\text { Dilated bowel loops. Barium } \\
\text { enema: microcolon }\end{array}$ \\
\hline 7 & $\mathrm{~F}$ & 39 & At birth & 3500 & $\begin{array}{l}\text { Not fed, abdominal distension, } \\
\text { bilious gastric aspirate }\end{array}$ & $\begin{array}{l}\text { Air bubble in the stomach, no } \\
\text { air in the rest of the bowel. } \\
\text { Barium enema: proximal } \\
\text { bowel dilatation microcolon }\end{array}$ \\
\hline 8 & $\mathbf{M}$ & 40 & 7 hours & 3000 & $\begin{array}{l}\text { Breast fed, abdominal distention, } \\
\text { bilious vomiting }\end{array}$ & $\begin{array}{l}\text { Paucity of air in the abdomen, } \\
\text { free air under diaphragm }\end{array}$ \\
\hline
\end{tabular}


in the development of bronchopulmonary dysplasia. Despite irrigation of the bowel with $N$ acetylcysteine at laparotomy, no meconium was passed, and further surgery was required at day 14 of life after a rectal perforation. Several attempts at extubation failed and this baby died at 4 months of age from lower respiratory infection, superimposed on chronic lung disease. With the exception of patients 2 and 6, all infants in our series had normal chest radiographs.

\section{Discussion}

Although all of the newborns described presented with meconium obstruction of the terminal ileum, none had clinical or laboratory evidence of cystic fibrosis. Meconium intestinal obstruction in the neonatal period can be due to three conditions (1) meconium ileus; (2) meconium plug syndrome; and (3) meconium disease (inspissated meconium syndrome).

Meconium ileus is due to mechanical obstruction of the terminal ileum with thick, viscid meconium, and in about $50 \%$ of cases is complicated by volvulus, atresia, or meconium peritonitis. ${ }^{4}$ In cystic fibrosis, meconium ileus is thought to result from abnormal mucus production in the intestine ${ }^{2}$ and/or impaired pancreatic enzyme or fluid secretion. ${ }^{5}$ Meconium ileus rarely occurs in infants without cystic fibrosis, ${ }^{6}$ but has been reported with pancreatic duct stenosis, ${ }^{7}$ partial pancreatic aplasia, ${ }^{8}$ ileocaecal atresia ${ }^{9}$ as a familial condition ${ }^{10} 11$ and a functional disorder in preterm babies. ${ }^{12}$ The meconium plug syndrome has also been reported in cystic fibrosis. ${ }^{13}$ In this condition, transient obstruction of the distal colon occurs, although meconium plugs in the ileum may cause complications, requiring surgery. ${ }^{14}$ Meconium disease has been described in premature infants with very low birth weight and is not associated with cystic fibrosis. ${ }^{15}$ In this condition meconium plugs are found in the distal ileum and proximal colon and the resulting obstruction can generally be relieved by enemas.

Although overlap between the three causes of meconium obstruction may occur, the cases we report most closely resemble meconium ileus. ${ }^{4}$ In addition, typical complications of meconium ileus occurred in five of our cases, necessitating surgical intervention. However, sweat tests were negative in all of our patients, none had clinical or laboratory evidence of pancreatic insufficiency, and the most common deletion associated with cystic fibrosis $\left(\Delta \mathbf{F}_{508}\right)^{3}$ was not present in the six infants who had genetic studies. We feel confident, therefore, that our patients did not have cystic fibrosis.

Meconium ileus in the absence of cystic fibrosis is considered a rare event and has been reported in only a few cases, ${ }^{16-18}$ sometimes as a familial condition. ${ }^{1011}$ However, $21.6 \%$ of our patients with meconium ileus did not have cystic fibrosis. Although the exact cause of meconium ileus is unclear, four out of eight of the babies described were born prematurely (<37 weeks' gestation), three of whom required mechanical ventilation. It is possible that reduced intestinal motility may have contributed to the development of meconium ileus in these infants.

In summary, our report indicates that a significantly greater number of newborn infants with meconium ileus will not have cystic fibrosis than has been previously described. Definitive parental counselling should, therefore, be delayed until accurate sweat chloride tests can be obtained.

The authors thank J Chay for secretarial assistance.

1 Kerem E, Corey M, Kerem B, et al. Clinical and genetic comparisons of patients with cystic fibrosis, with or without meconium ileus. 7 Pediatr 1989;114:767-73.

2 Thomaidis TS, Arey JB. The intestinal lesions in cystic fibrosis of the pancreas. 7 Pediatr 1963;63:444-53.

3 Kerem B, Rommens JM, Buchanan JA, et al. Identification of the cystic fibrosis gene: genetic analysis. Science 1989;245: $1073-80$

\begin{tabular}{|c|c|c|c|}
\hline Operative findings & $\begin{array}{l}\text { Genetic } \\
\text { analysis }\end{array}$ & Treatment & Outcome \\
\hline $\begin{array}{l}\text { Meconium ileus, meconium obstructing } \\
\text { the ileocaecal valve. No atresia }\end{array}$ & Not done & Bowel flushed with $\mathrm{N}$-acetylcysteine & $\begin{array}{l}\text { No complications. Normal faecal fat and } \\
\text { bentiromide study }\end{array}$ \\
\hline $\begin{array}{l}\text { Meconium ileus with perforation } \\
\text { of mid-ileum }\end{array}$ & Negative for $\Delta F_{508}$ & $\begin{array}{l}5 \mathrm{~cm} \text { ileal resection and end to end } \\
\text { anastomosis }\end{array}$ & $\begin{array}{l}\text { No nutritional or gastrointestinal } \\
\text { problems. Serum trypsinogen normal. } \\
\text { Mild BPD }\end{array}$ \\
\hline $\begin{array}{l}\text { Meconium peritonitis. Meconium cyst: } \\
\text { ileal atresia with perforation }\end{array}$ & Negative for $\Delta \mathrm{F}_{508}$ & $\begin{array}{l}10 \mathrm{~cm} \text { small bowel resection, } \\
\text { and ileostomy }\end{array}$ & $\begin{array}{l}\text { No nutritional, gastrointestinal, or } \\
\text { respiratory problems }\end{array}$ \\
\hline $\begin{array}{l}\text { Meconium ileus with mid-ileal } \\
\text { volvulus and perforation }\end{array}$ & Not done & $\begin{array}{l}10 \mathrm{~cm} \text { small bowel resection with } \\
\text { end to end anastomosis and irrigation } \\
\text { of distal bowel with } N \text {-acetylcysteine }\end{array}$ & $\begin{array}{l}\text { Jejenostomy required for small bowel } \\
\text { dehiscence. No nutritional or } \\
\text { respiratory problems }\end{array}$ \\
\hline No surgery & Negative for $\Delta \mathrm{F}_{508}$ & $\begin{array}{l}N \text {-acetylcysteine by nasogastric tube } \\
\text { and enema }\end{array}$ & $\begin{array}{l}\text { No nutritional or respiratory problems. } \\
\text { Normal faecal fat study and } \\
\text { serum trypsinogen }\end{array}$ \\
\hline Meconium ileus, microcolon & Negative for $\Delta \mathrm{F}_{508}$ & Bowel flushed with $\mathrm{N}$-acetylcysteine & $\begin{array}{l}\text { Severe BPD. Rectal perforation day } 14 . \\
\text { Died from respiratory failure } \\
\text { at } 4 \text { months }\end{array}$ \\
\hline $\begin{array}{l}\text { Segmental ileal volvulus at mid-ileum } \\
\text { meconium cyst, and associated } \\
\text { ileal atresia }\end{array}$ & Negative for $\Delta \mathrm{F}_{508}$ & $\begin{array}{l}\text { Meconium cyst resection, side to end } \\
\text { anastomosis }\end{array}$ & Normal trysinogen value \\
\hline $\begin{array}{l}\text { Perforated distal ileum, meconium } \\
\text { peritonitis }\end{array}$ & Negative for $\Delta F_{508}$ & Ileostomy, no bowel resection & Raised trypsinogen value \\
\hline
\end{tabular}


4 Park RW, Grand RJ. Gastrointestinal manifestation of cystic fibrosis: a review. Gastroenterology 1961;81: cystic fib

5 Lands L, Zinman R, Wise M, Kopelman L. Pancreatic function testing in meconium disease in CF: two case reports. F Pediatr Gastroenterol Nutr 1988;7:276-9.

6 Donnison AB, Shwachman H, Gross RE. A review of 164 children with meconium ileus seen at the Children's Hospital Medical Center, Boston. Pediatrics 1966;57: 833-50.

7 Hurwitt E, Arneheim E. Meconium ileus associated with stenosis of the pancreatic ducts. Am $\mathcal{F}$ Dis Child 1942; 64:443-54

8 Auburn R, Feldman S, Gadacz T, Towe M. Meconium ileus secondary to partial aplasia of the pancreas: report of a case. Surgery 1969;65:689-93.

9 Ein SH, Mancer K. Ileocecal atresia. F Pediatr Surg 1963; 20:525-8.

10 Dolan TF, Touloukian RJ. Familial meconium ileus not associated with cystic fibrosis. I Pediatr Surg 1974;9: associated

11 Tal A, Carmi R, Chai-Am E, Zirkin H, Bar-Ziv J, Freud E.
Familial meconium ileus with normal sweat electrolytes. Clin Pediatr (Phila) 1985;24:460-2.

12 Siche WK in newborn infants with morphologically normal gastroinin newborn infants with morphologically normal

13 Rosenstein BJ, Langbaum TS. Incidence of meconium abnormalities in newborn infants with cystic fibrosis. $A m$

14 Talwalker VC, Kittur DH. Ileal meconium plugs. Arch Dis Child 1980;55:288-91.

15 Vinograd I, Megle P, Peleg O, Alpan G, Lernau OZ. Meconium disease in premature infants with low birth weight. $₹$ Pediatr 1983;103:963-6.

16 Shigemoto $\mathrm{H}$, Endo S, Isomoto T, Sano K, Taguchi K Neonatal meconium obstruction in the ileum without mucoviscidosis. $\mathcal{F}$ Pediatr Surg 1978;13:475-9.

17 Rickman PP, Boeckman CR. Neonatal meconium obstruction in the absence of mucoviscidosis. Am $\mathcal{f}$ Surg tion in the absen.

18 Olsen MM, Luck SR, Lloyd-Still J, Raffensperger JG. The spectrum of meconium disease in infancy. $\mathcal{F}$ Pediatr Surg $1982 ; 17: 479-81$. 